\title{
Quantifying Landscape Structure of the Kelantan River Basin Before and After a Major Flood Event Using Landscape Metrics
}

\author{
Abdul, H. Y., ${ }^{1}$ Amal, N. M. N., ${ }^{2 *}$ Sofiyan, S., ${ }^{3}$ Nur, H. R., ${ }^{4}$ Roniza, I. $^{2}$ and Kamarul, H. ${ }^{2}$ \\ ${ }^{1}$ Faculty of Bioengineering and Technology, Universiti Malaysia Kelantan, Jeli Campus, Jeli, Kelantan, \\ Malaysia \\ ${ }^{2}$ Faculty of Earth Sciences, Universiti Malaysia Kelantan, Jeli Campus, Jeli, Kelantan, Malaysia \\ E-mail: amalnajihah@umk.edu.my \\ ${ }^{3}$ School of Ocean Engineering, Universiti Malaysia Terengganu, Malaysia \\ ${ }^{4}$ Institute for Environment and Development, Universiti Kebangsaan Malaysia, Bandar Baru Bangi, Selangor \\ Malaysia \\ *Corresponding Author
}

DOI: https://doi.org/10.52939/ijg.v17i4.1953

\begin{abstract}
Over the years, flood is one of the natural hazards which occur all over the world and it is critical to be controlled through proper management. Flood in Kelantan is mainly caused by heavy rainfall brought by the Northeast monsoon starting from November to March every year. It is categorized as annual flood as it occurs every year during the Monsoon season. Severe flood events in Kelantan, Malaysia cause damage to both life and property every year and understanding landscape structure changes is very important for planners and decision makers for future land use planning and management. This research aims to quantify the landscape structure near to Kelantan River basin during the flood event using integrated approach of remote sensing (RS), geographic information system (GIS) technique and landscape ecological approach. As a result, this study provide new knowledge on landscape structure that contributes to understand the impact of flood events and provide the best ways to mitigate flooding for helping to protect biodiversity habitat and dwellers. As conclusions, this kind of study will give more benefits to various stakeholders such as Department of Irrigation and Drainage, Department of Environment, state government, fisherman and communities.
\end{abstract}

\section{Introduction}

Heavy monsoons rainfalls have triggered floods along Malaysia's east coast as well as in different parts of the country. The hardest hit areas are along the east coast of peninsular Malaysia in the states of Kelantan, Terengganu and Pahang. Recently the major flood event in Kelantan was occurred in year 2014. The flood cost nearly millions of dollars of property and many lives. Floods are considered to be one of the weather-related natural disasters. Many methods exist to provide qualitative estimations of the risk level of flood susceptibility mapping within a watershed (Khan et al., 2014 and Ghorbani et al., 2016). Problems related to flooding have greatly increased, and there is a need for an effective modelling to understand the problem and mitigate its disastrous effects. Human activities such as unplanned rapid settlement development, uncontrolled construction of buildings in general and major land use changes can influence the spatial and temporal pattern of hazards. There are several factors contributing to the flooding problem ranging from topography, geomorphology, drainage, engineering structures, and climate. Most floods are caused by storms in which a lot of precipitation falls in a short period of time, of both types of rainfall, convective and frontal storms. Intensity and duration of the rain are the most influencing factors for flood hazards. In the recent years, remote sensing and Geographic information systems have been embedded in the evaluation of the geo-environmental hazards. Development of agriculture and residential are the main drivers of forest clearance in Malaysia (Hughes, 2018). Forest clearances create impacts on the degradation of wildlife habitat, cause erosion and trigger flooding. The conversion of landscape to several small and medium-scale development projects by private and government agencies is sooner or later will change 
their functional role for natural ecosystem sustainability.

Geographically, most of the area in Kelantan is considered as flood-prone area (Pradhan and Shafie, 2009 and Khan et al., 2014). Land utilization without proper planning will diminish the 'ponding' function for flood mitigation. Thus, the whole area will be exposed to high risks of a severe flood in the future and loss of wildlife habitat. The landscape natural habitat functions as a 'ponding basin' during the annual flood season (November-January), site of migratory birds and habitat of several rare wildlife species, natural maintenance of underground water level and prevention of underground salt water intrusion (Vallejo et al., 2009). Thus, this valuable information would certainly enable the concerned government and private authorities to plan, design and construct the most suitable land use planning in mitigating flood events.

However, currently in Malaysia the model used for quantifying the impact of flood event were high capital cost, yearly maintenance fees, expensive expertise cost, limited function, longer processing time and lack of expert. Therefore the key future need is for flood modelling technique and associated data that make it faster to build and run models. The systems need extended functionality to quickly generate the robust outputs that the modellers are asked to provide. The results need to be more accurate, more detailed and easier to use. The modelling processes needs to be more efficient and the modelling systems more intelligent so that only 'fit for purpose' results are generated. Therefore, land change structure is needed as an essential tool in developing flood mitigation.

Modeling techniques using remote sensing and GIS have been popular tools as the principal information source in the assessment of hazards or disasters. There have been many studies on flood susceptibility mapping using remote sensing data and GIS tools. Radar remote sensing data have been extensively used for flood monitoring across globe and many of these studies have applied using probabilistic methods (Pradhan and Shafie, 2009, Li et al., 2012 and Uuemaa et al., 2013).

Nonetheless, the spatial structure and functions of historical, current and future changes in river basin landscape remain unexplored. Integrated of Remote Sensing, Geographical Information System and landscape ecological approach provide a comprehensive approach to understand the landscape structure and function. Consequently, improved structures and functions of landscape patches will be achieved. Therefore, the formulated research question in this study is how the landscape structure changes did after the flood events. The objective of this project is to quantify the spatial patterns of landscape structure surrounding Kelantan River Basin before and after the flood events.

\section{Materials and Methods}

\subsection{Study Area}

This study focused on Kelantan River Basin near to Kota Bharu (Figure 1). The KRB $\left(12,134 \mathrm{~km}^{2}\right)$ is one of the major basins in Malaysia (Figure 1). It is occupies more than $80 \%$ of the Kelantan state in north-eastern Peninsular Malaysia. The basin lies between latitudes $4^{\circ} \mathrm{N}$ to $6^{\circ} \mathrm{N}$ and longitudes $\mathrm{E}$ to E. The elevation varies from 8 to $2174 \mathrm{~m}$ above mean sea level, with mountains in the west and southwest regions. The Kelantan River is about $248 \mathrm{~km}$ long and originates from the Titiwangsa and Tahan mountain ranges. The basin surrounded by the South China Sea in the north of Pangkalan Datu River, Pengkalan Chepa river in the east, Pendek River district in the South and Kelantan River in the west. The daily temperature in Kota Bharu is approximately $26^{\circ} \mathrm{C}$. The average rainfall for each year is $2,700 \mathrm{~mm}$ and it rises in October, November and December, increased significantly from 1985 to 2014. For instance, a massive flood occurred in 2004 resulted in the evacuation of more than 10,000 people, caused losses of about USD\$ 370 million and 12 deaths (Tan et al., 2017).

\subsection{Methodology}

In this study, landscape surrounding Kelantan River Basin were analysed using Erdas Imagine 2014 and ArcGIS 10.3 to derive the spatial distribution landscape maps of Delta Kelantan area. The landscape analysis consist of three stages. The first stage involve the image processing using statellite images of 1988, 2003 and 2019. Next, the second stage involved producing land use/land cover maps of study areas and lastly analysing the spatial structure changes of the study area to detect differences in spatial structure (Figure 2).

\subsection{Data Acquisition and Processing}

Land use/land cover (LULC) maps of 1988, 2003 and 2019 were derived from image processing using Erdas Imagine 2014. The LULC were reclassified into five types i) built up area, ii) forest, iii) other agriculture, iv) waterbody, v) paddy. 


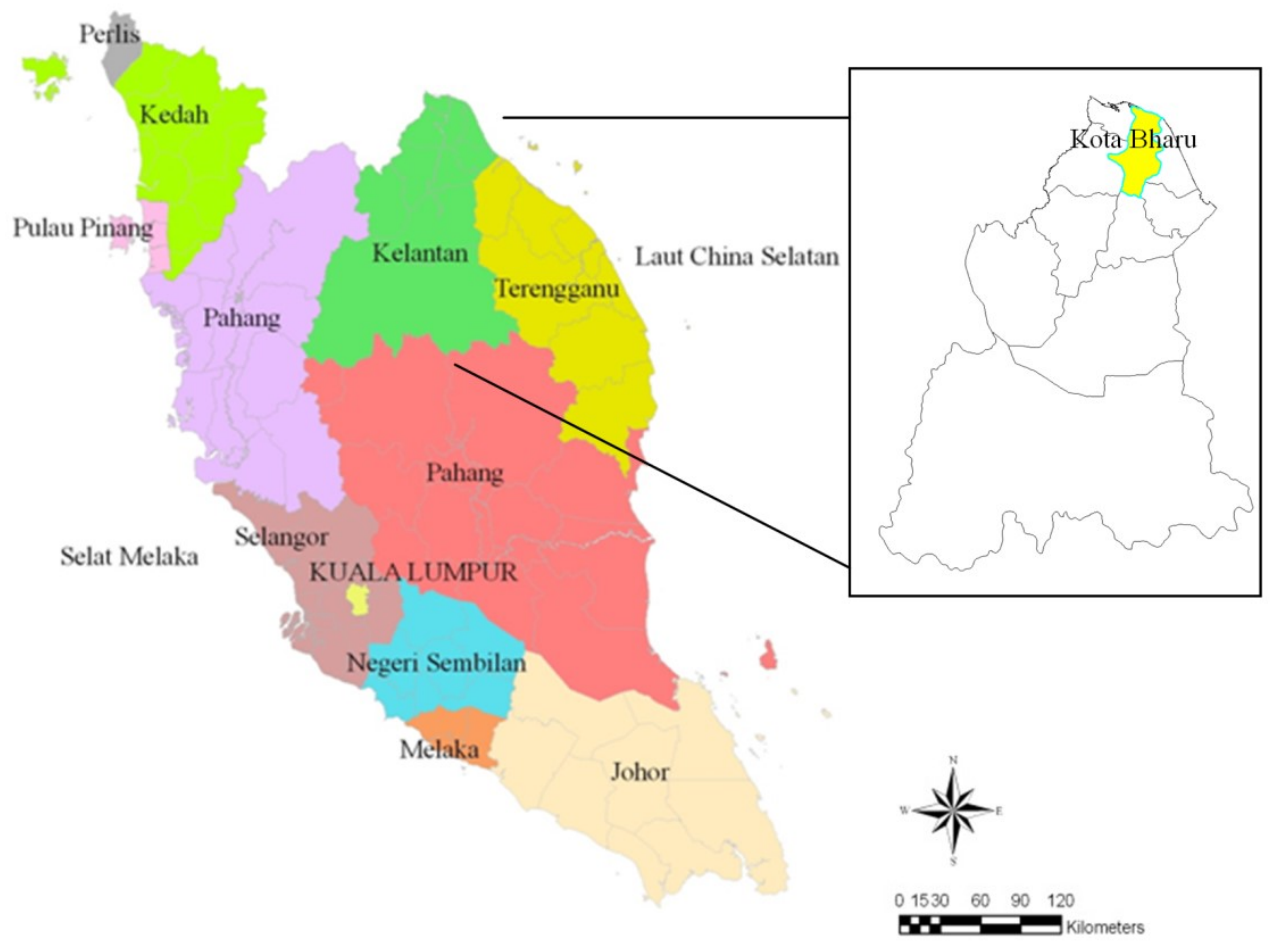

Figure 1: Location of Kota Bharu, Kelantan in Peninsular Malaysia

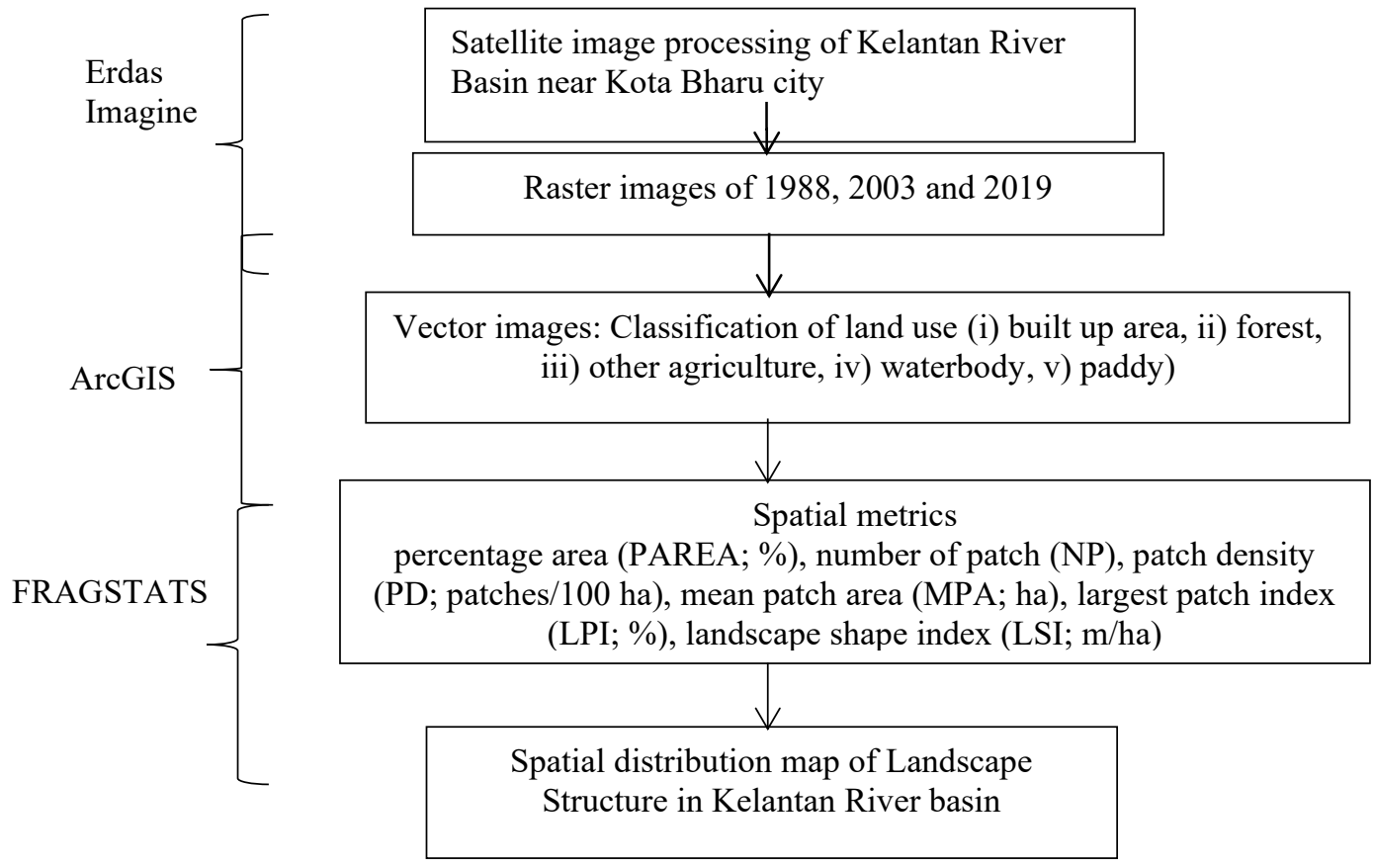

Figure 2: Methodological framework for spatial flood planning

The overall accuracy for the three maps was over $80 \%$ which is acceptable for the next analyses. The maps were used to analyze landscape structure in Kelantan river Basin near to Kota Bharu. The land use plans were obtained from Department of Agriculture. These data sets were converted to vector and raster grid file formats for spatial structure analysis. 


\subsection{Groudthruthing and Data Collection}

Groudthruthing was conducted to collect data on the variable factors such as waterbody, road, agriculture area and built up area by using survey and Global Positioning System (GPS).

\subsection{Data Analysis}

\subsubsection{Landscape Changes}

Landscape change were analysed using spatial analysis in ArcGIS. The tools calculated the area of class in landscape using hectares for each year of 1988, 2003 and 2019.

\subsubsection{Landscape Structure Analysis}

Landscape structure were analysed in FRAGSTATS software (McGarigal et al., 2002), at the landscape and class level using six landscape metrics: percentage area (PAREA; \%), number of patch (NP), patch density (PD; patches/100 ha), mean patch area (MPA; ha), largest patch index (LPI; \%), landscape shape index (LSI; m/ha) (Table 1). All of these landscape metrics were used to characterize the changes in land use/land cover of landscape criteria such as isolation of patches (number of patch), variety of shape (landscape shape index) and size of patches (percentage area and largest patch index) (Nor et al., 2020). The landscape metrics of patch density (PD; patches/100 ha) and mean patch area (MPA; ha) had been chosen to evaluate all the five LULC class in all the three respective years in 1988, 2003 and 2019 at the landscape level to understand the landscape transformation process that occurred in the study area.

\section{Results and Discussion}

\subsection{Landscape Changes}

Figure 3 shows the landscape change of Delta Kelantan in year 1988, 2003 and 2019. Built-up areas show the huge transition from 1988 to 2019. It is because the main activities for land use in Kota Bharu such as agriculture, residential area, animal livestock and aquaculture, water reserves, vacant land and coastal areas. The built-up area experienced the rapid increase from 1988 to 2019 with the increase of $9.3 \%$ (Figure 4). Similar with other agriculture also show the same pattern with the increase of $2.4 \%$. However, forest, paddy and waterbody decreased about $0.3-11 \%$ from 1988 to 2019. Paddy show the highest decreased of area in 2019 (Figure 4). This is indicated that paddy was transformed into built-up area to develop the commercial area and residential area. The comparison between land use transition from 1988 to 2003 and from 2019 and 2019 show that the forest area was constantly decreased for both periods with the same percentage of $0.2 \%$.

Table 1: Landscape metrics analysis

\begin{tabular}{|c|c|c|c|}
\hline Landscape metrics & Description & Units & Range \\
\hline $\begin{array}{l}\text { Number of patches } \\
\text { (NP) }\end{array}$ & $\begin{array}{l}\mathrm{n}_{\mathrm{i}}=\text { number of patches in the } \\
\text { landscape of patch type (class) } \mathrm{i} \text {. }\end{array}$ & Number & None \\
\hline Patch density (PD) & $\begin{array}{l}\mathrm{PD}=\underline{\mathrm{n}}_{\mathrm{i}}(10000)(100) \mathrm{A} \\
\text { The number of patches per } 100 \text { ha }\end{array}$ & $\begin{array}{l}\text { Number per } \\
100 \text { hectares }\end{array}$ & $\begin{array}{l}\mathrm{PD}>0 \text {, constrained } \\
\text { by cell size }\end{array}$ \\
\hline $\begin{array}{l}\text { Mean patch area } \\
\text { (MPA) }\end{array}$ & $\begin{array}{l}\text { MN }=n \sum \frac{\mathrm{xij}=1}{n_{i}} \\
\text { The area occupied by a particular } \\
\text { patch type divided by the number } \\
\text { of patches of that type }\end{array}$ & Hectares & MPS $>0$, no limit \\
\hline $\begin{array}{l}\text { Largest patch index } \\
\text { (LPI) }\end{array}$ & $\begin{array}{l}\text { LPI }=\max (\mathrm{a})_{\mathrm{ij}} \\
(100) \mathrm{A} \\
\text { LPI equals the area }(\mathrm{m} 2) \text { of the } \\
\text { largest patch of the corresponding } \\
\text { patch type divided by total } \\
\text { landscape area (m2), multiplied by } \\
100 \text { (to convert to a percentage) }\end{array}$ & Percent & $0<\mathrm{LPI}<100$ \\
\hline $\begin{array}{l}\text { Landscape shape index } \\
\text { (LSI) }\end{array}$ & $\begin{array}{l}\text { LSI = the total length of edge (or } \\
\text { perimeter) divided by the minimum } \\
\text { length of class edge (or perimeter) }\end{array}$ & $\begin{array}{l}\text { LSI } \geq 1 \text {, without } \\
\text { limit. }\end{array}$ & None \\
\hline
\end{tabular}


a)

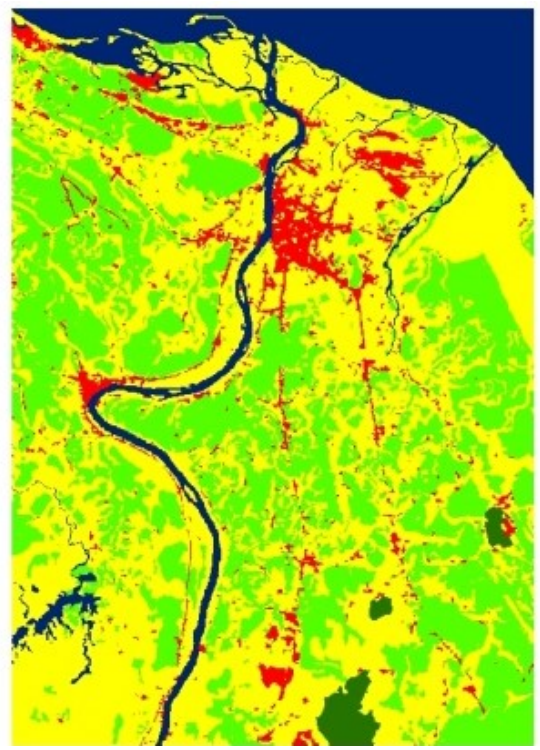

c)

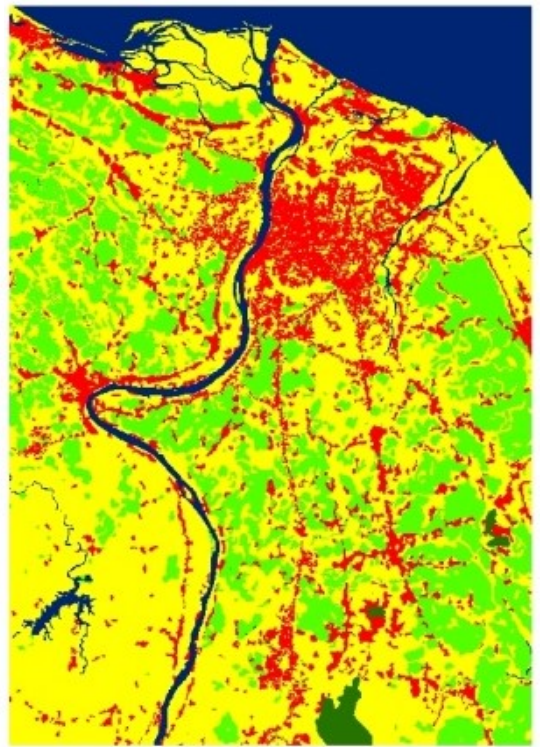

b)

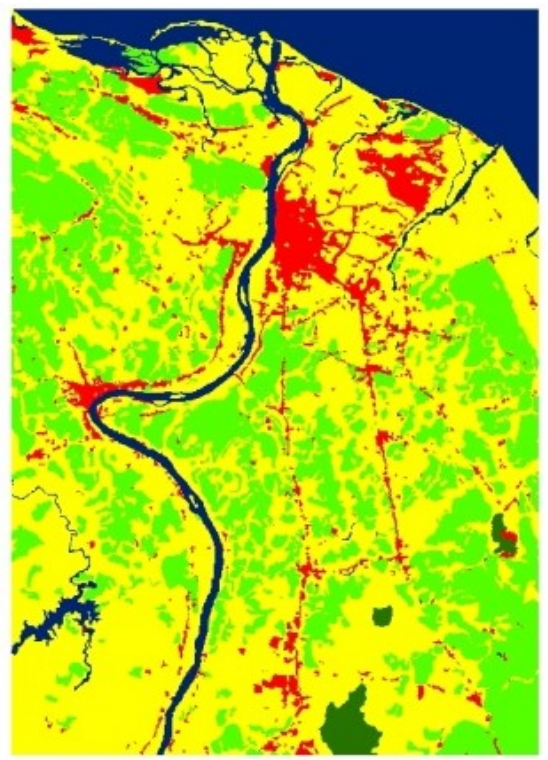

\section{Legend}

built-up area

forest

other agriculture

paddy

waterbody

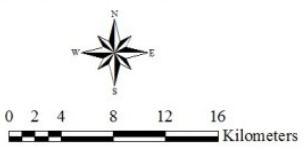

Figure 3: The land use maps of Delta Kelantan in year a) 1988, b) 2003 and c) 2019

\subsection{Landscape Structure Analysis}

The distribution of land use in Kelantan River Basin showed a different spatial pattern of landscape and class level in all three years (Table 2). In the landscape level, the landscape metric values in year 2019 showed that the largest number of patch (NP), patch density (PD) and landscape shape index (LSI) compared with landscape metrics value in year 2003 and 1988 (Table 2). This indicates that the patch size, density and shape of patches in 2019 is greater and there is variety of shape of patches compared with year 2003 and 1988. Kelantan River Basin indicate a different spatial pattern with fragmented landscape exhibiting a variety of shapes but with increased in size and density of patches in 2019 compared with 1988 as indicated by the higher number of patch, patch density (PD) and landscape shape index (LSI).

By contrast, we examined landscape patch index (LPI) and mean patch area (MPA) for class level in the Kelantan River Basin (Table 3). In 1988 and 2003, Kelantan River Basin exhibits higher landscape patch index (LPI) values in other agriculture compared with other LULC indicating that their size of patches is bigger compared to the other LULC. In 2019, the fragmentation metrics (LPI, MPA) are higher in waterbody and forest respectively (Table 3) indicating that forest is fragmented with larger mean patch areas. 
Table 2: Landscape metric value in landscape level

\begin{tabular}{|l|l|l|l|}
\hline $\begin{array}{c}\text { Year/ } \\
\text { Landscape Metric }\end{array}$ & \multicolumn{1}{|c|}{ NP } & \multicolumn{1}{c|}{ PD } & LSI \\
\hline 1988 & 1386 & 1.18 & 1.31 \\
\hline 2003 & 1023 & 0.87 & 1.36 \\
\hline 2019 & 1685 & 1.44 & 1.37 \\
\hline
\end{tabular}

Table 3: Landscape metric value in class level

\begin{tabular}{|l|r|r|r|r|r|r|}
\hline Year/ & \multicolumn{2}{|c|}{1988} & \multicolumn{2}{c|}{2003} & \multicolumn{2}{c|}{2019} \\
\hline $\begin{array}{l}\text { Land use types/ } \\
\text { Landscape metric }\end{array}$ & \multicolumn{1}{c|}{ LPI } & \multicolumn{1}{c|}{ MPA } & \multicolumn{1}{c|}{ LPI } & MPA & LPI & MPA \\
\hline Built-up area & 1.1 & 9.6 & 1.5 & 14.7 & 4.0 & 23.5 \\
\hline Forest & 0.8 & 418.6 & 0.7 & 356.6 & 0.6 & 176.0 \\
\hline Other agriculture & 27.4 & 203.8 & 29.4 & 321.5 & 11.0 & 120.4 \\
\hline Paddy & 5.4 & 97.0 & 4.8 & 133.7 & 2.7 & 71.0 \\
\hline Waterbody & 11.1 & 143.9 & 11.4 & 168.0 & 17.7 & 125.5 \\
\hline
\end{tabular}

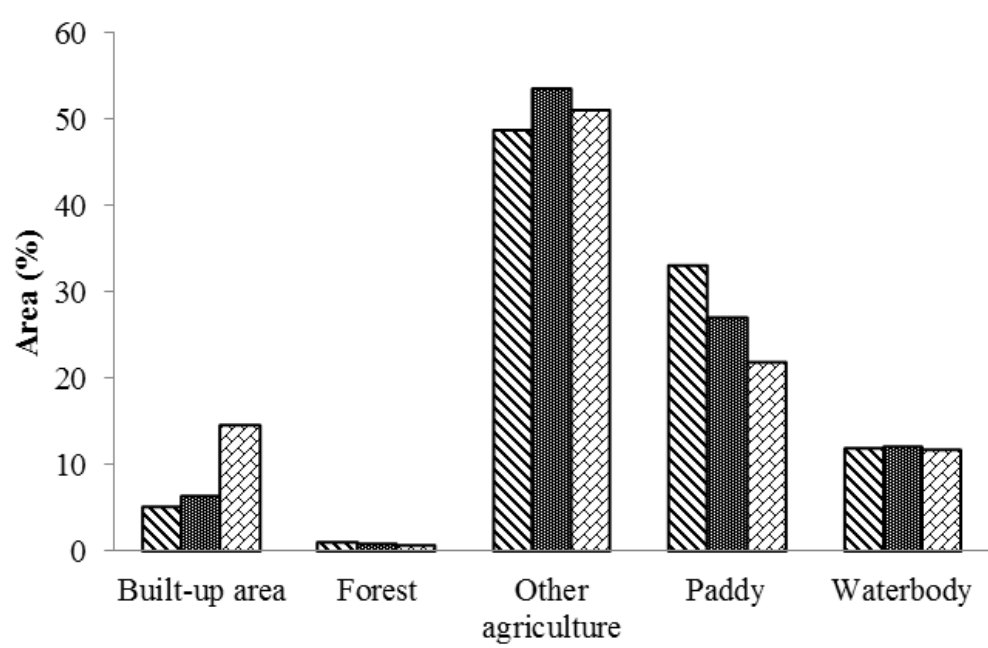

Land use types

Figure 4: Percentage of area in year a) 1988, b) 2003 and c) 2019

However, waterbody is aggregated, larger in size, illustrated by the high landscape patch index and mean patch area. In comparison, built up area spatial pattern show that the patch area are become larger indicated by the increased value of landscape patch index (LPI). Similar with waterbody, also exhibits the same pattern. However, landscape patch index (LPI) of forest and paddy show a decreased of value from 1988 to 2019. This indicated that the patch area are become smaller and shrink (Table 3 ).

This research information contributes to the understanding of the dynamics of current changes in LULC structure (Figure 3, Table 2 and Table 3) before and after the flood event. The historical spatial changes were influenced by unpredictable events such as flood events, natural disaster and uncontrolled planning policies. This work has shown how an integrated landscape ecology approach in LULC has the capability to quantify the spatial effects of flood events. The model provides the empirical evidence and illustrating possibly improvements to inform effective planning to undertake the flood events. This study illustrates a novel approach to identify evidence of past or current planning interventions. This is particularly critical in the flood prone area, where assessing the relative impact and degree of the impact of flooding can have is often difficult to obtain. 
The transition of forest into the built-up areas has recognized one of the major threat for habitat degradation worldwide (Nor et al., 2017) and therefore, when the flood comes it will triggered the impact to be bigger. Ineffective urban development planning can cause changes to the composition and configuration of green space (Kukkonen et al., 2018 and Azami et al., 2019). In Kelantan River Basin, lack of monitoring poses challenges for the adoption of appropriate flood mitigation strategies. In addition, Kelantan River Basin shows an increase of monthly rainfall during the wet season, and decrease during the dry season. Therefore, the monthly streamflow and surface runoff are likely to increase significantly in November, December and January (Tan et al., 2017). The similar pattern of landscape structure can be seen in waterbody of Kelantan River Basin, indicated by the increase of largest patch index (LPI) and mean patch area (MPA) (Table 3).

The evidence of the impact of flood events to the landscape in Kelantan River Basin in difference in the size, density, shape, and spatial configuration of landscape features in the period between 1988 and 2019. Based on the interpretation of spatial pattern such as fragmentation, aggregation, compaction, dispersion and isolation (Aguilera et al., 2011) we were able to use spatial metrics to compare and identify the land use patterns resulting before and after the flood events. The several studies also use remote sensing and GIS tools to detect flood events in Kelantan River Basin (Tan et al., 2017, Ibrahim et al., 2017 and Udin et al., 2018). However, in this research, the use of spatial metrics allowed for quantifying and categorizing complex landscape dynamics into simple, quantifiable and identifiable patterns. This is the first quantitative study to assess the effect of major flood events on the spatial pattern of landscape. The various landscape metrics such as built up area density, aggregation and compaction define by patch density (PD), mean patch area (MPA), largest patch index (LPI) and landscape shape index (LSI) provide a measure of LULC and helps link pattern and processes (Nor et al., 2018). The development of these spatial patterns is influenced by the urban expansion, regulatory history of their respective regions and municipalities and natural disasters (Nor et al., 2017 and 2018). The pattern and processes describe here can be used to inform planning and policies in other flood prone area.

Lack of mitigation planning on flood events influences the structure and pattern of land use and consequently affects the fragmentation of forest. For instance, in Kelantan River Basin, the major flood events in 2014 would result in the decreased value of largest patch index in forest and paddy area. In the meantime, built-up areas increasing in size and exhibit less variety of shape (indicating the aggregation and compaction of built-up areas) (Table 3). The aggregation and compaction of builtup areas results in the dislocation, dispersion and isolation of green space (Table 3); in which the forest are smaller, with less shape complexity. This suggesting that there should be an initiative to develop and optimize the green space structure to mitigate the flood events.

Given the established importance of forest and waterbody structure and the potential for encroached green spaces to become too small and isolated to meet user demands (Tian et al., 2011), it is clear that Kelantan River Basin is at risk of losing green space function in the future as well as to mitigate the flood events. From this study, there is evidence that flood events have influenced the LULC structure, and their planning is important to guide mitigation strategies improvement to planning, monitoring and manage forest area. Based on results from these study, the planning authorities could design interventions which support planning at the landscape and class level (Nor and Abdullah, 2019) with a better understanding of the spatial configurations of flood prone river landscapes.

\section{Conclusion}

This study sought to quantify the spatial patterns of landscape structure surrounding Kelantan River Basin before and after the flood events and suggest the best strategies to mitigate the flood events. The huge changes of patch size, density and shape of patches in 2019 compared with year 2003 and 1988 indicate that the flood events effect the landscape changes of the study area and these could consequently affect the habitat and well-being of dwellers. This study establish that areas potentially exposed to flooding can be located at low forest density, and within different jurisdictions, from upstream areas where the flood hazard may be generated and could be moderated via functions provided by green infrastructure landscapes. This raises planning and governance challenges connected to supporting and enhancing flood risk management functions provided by green landscapes. Therefore, this study is important and timely as it highlights the planning problems faced by flood prone area, distinguish the potential area to improve the green landscape and propose a new integrated methodology for quantifying landscape structure that can be used by administrative planners and decision makers to assess, understand and monitor the impact flood events. 


\section{Acknowledgment}

Special thanks to Universiti Malaysia Kelantan, and Institut Perubahan Iklim, Universiti Kebangsaan Malaysia for providing facilities and support for this research. This research is supported by short term grant project funded by Kursi Perubahan Iklim UKM-YSD (R/YSD/A1300/01684A/002/2019/00608) funded by Institut Perubahan Iklim Universiti Kebangsaan Malaysia and partially supported by Skim Geran Penyelidikan UMK Covid-19 Special Grant (UMK-C19SG) (R/C19/A0800/00793a/003/2020/00779).

\section{References}

Aguilera, F., Valenzuela, L. M. and BotequilhaLeitao, A., 2011, Landscape Metrics in the Analysis of Urban Land Use Patterns: A Case Study in a Spanish Metropolitan Area. Landscape and Urban Planning, Vol. 99(3-4), 226-238. DOI: https://doi.org/10.1016/j.landurbplan.2010.10.004.

Azami, M. H., Faheem, M., Aabid, A., Mokashi, I. and Khan, S. A., 2019, Inspection of Supersonic Flows in a CD Nozzle Using Experimental Method. International Journal of Recent Technology and Engineering, Vol. 8(2S3) 996999. DOI: http://doi.org/10.35940/ijrte.B1186.0782S319.

Ghorbani, K., Wayayok, A. and Abdullah, A. F., 2016, Simulation of Flood Risk Area in Kelantan Watershed, Malaysia Using Numerical Model. Jurnal Teknologi, Vol. 78(1-2), 51-57. DOI: https://doi.org/10.-11113/jt.v78.7260.

Hughes, A. C., 2018, Have Indo-Malaysian forests reached the end of the road?. Biological Conservation, Vol. 223, 129-137. DOI: https://doi.org/10.1016/j.biocon.2018.-04.029.

Ibrahim, N. F., Zardari, N. H., Shirazi, S. M., Mohd Haniffah, M. R., Mat Talib, S., Yusop, Z. and Mohd Yusoff, S. M. A., 2017, Identification of Vulnerable Areas to Floods in Kelantan River Sub-basins by Using Flood Vulnerability Index. International Journal of GEOMATE, Vol. 12(29), 107-114. DOI: http://doi.org/10.21660/2017.29.11110.

Khan, M. M. A., Shaari, N. A., Bahar, A. M. A. and Baten, M. A., 2014, Impact of the Flood Occurrence in Kota Bharu Using Statistical Analysis. Journal of Applied Science, Vol. 14(17), 1944-1951. DOI: http://doi.org/10.3923/jas.2014.1944.1951.
Kukkonen, M. O., Muhammad, M. J., Käyhkö, N. and Luoto, M., 2018, Urban Expansion in Zanzibar City, Tanzania: Analyzing Quantity, Spatial Patterns and Effects of Alternative Planning Approaches. Land Use Policy, Vol. 71, 554-565, DOI: https://doi.org/10.1016/j.landusepol.2017.11.007.

Li, X., Zhou, W., Ouyang, Z., Xu, W. and Zheng, H., 2012, Spatial Pattern of Greenspace Affects Land Surface Temperature: Evidence from the Heavily Urbanized Beijing Metropolitan Area, China. Landscape Ecology, Vol. 27 (6), 887898. DOI: https://doi.org/10.1007/s10980-0129731-6.

McGarigal, K., Cushman, S. A., Neel, M. C. and Ene, E., 2002, FRAGSTATS: Spatial Patternnanalysis Program for Categorical Maps. Computer Software Program Produced by the Authors at the University of Massachusetts. Amherst. Available http://www.umass.edu/landeco/research/fragstats/fragstats.html.

Nor, A. N. M., Corstanje, R., Harris, J. A. and Brewer, T., 2017, Impact of Rapid Urban Expansion on Green Space Structure, Ecological Indicators, Vol. 81, 274-284. DOI: https://doi.org/10.1016/j.ecolind.2017.05.031.

Nor, A. N. M., Isnorm, R. A., Abas, M. A., Malek, N. H. A., Hassin, N. H., Aziz, H. A., Omar, S. A. S. and Rafaai, N. H., 2018, Landscape Ecological Assessment of Potential Ecotourism in Malaysia. International Journal of Civil Engineering and Technology, Vol. 9 (10), 969979.

Nor, A. N. M. and Abdullah, S. A., 2019, Developing Urban Green Space Classification System Using Multi-Criteria: The Case of Kuala Lumpur City, Malaysia, Journal of Landscape Ecology, Vol. 12(1), 16-36. DOI: https://doi.org/10.2478/jlecol-2019-0002.

Nor, A. N. M., Bahri, A. S., Nor, S. M., Yusoff, A. H., Abas, M. A., Jamil, R. M. and Amin, M. F. M., 2020, Impact of Land Use Changes on Forest Catchment Area in Pergau Lake, Kelantan. In IOP Conference Series: Earth and Environmental Science, Vol. 549(1), 012006). IOP Publishing. DOI: https://doi.org/10.1088/1755-1315/549/1/012006.

Pradhan, B. and Shafie, M., 2009, Flood Hazard Assessment for Cloud Prone Rainy Areas in a Typical Tropical environment, Disaster Advances, Vol. 2(2), 7-15. 
Tan, M. L., Ibrahim, A. L., Yusop, Z., Chua, V. P. and Chan, N. W., 2017, Climate Change Impacts Under CMIP5 RCP Scenarios on Water Resources of the Kelantan River Basin, Malaysia. Atmospheric Research, Vol. 189, 1-10. DOI: http://doi.org/10.1016/j.a-tmosres.2017.01.008 .

Tian, Y., Jim, C. Y., Tao, Y. and Shi, T., 2011, Landscape Ecological Assessment of Green Space Fragmentation in Hong Kong, Urban Forestry \& Urban Greening, Vol. 10(2), 79-86. DOI: https://doi.org/10.1016/j.-ufug.2010.11.002

Udin, W. S., Ismail, N. A., Bahar, A. M. A. and Khan, M. M. A., 2018, GIS-based River Flood Hazard Mapping in Rural Area: A Case Study in
Dabong, Kelantan, Peninsular Malaysia. Asian Journal of Water, Environment and Pollution, Vol. 15(1), 47-55. DOI: http://doi.org/10.3233/AJW-180005.

Uuemaa, E., Mander, Ü. and Marja, R., 2013, Trends in the use of Landscape Spatial Metrics as Landscape Indicators: a Review, Ecological Indicators, Vol. 28, 100-106. DOI: https://doi.org/10.1016/j.ecolind.2012.07.018.

Vallejo, B. M., Aloy, A. B. and Ong, P. S., 2009, The Distribution, Abundance and Diversity of Birds in Manila's Last Greenspaces, Landscape and Urban Plannning, Vol. 89(3-4), 75-85. DOI: https://doi.org/10.1016/j.landurbplan.2008.10.01 3 . 